\title{
¿COMO EMPIEZAN LAS OBRAS DE SHAKESPEARE?
}

\author{
Cándido Pérez Gállego
}

Empieza la obra. Se oye un "tempestuous noise of thunder". El navio se tambalea mientras ruge el mar. Discuten el contramaestre y el capitán, y hablan del peligro de naufragio que les acecha. Escuchan los marineros alarmados. Sube entonces el rey Alonso de Nápoles y acompañantes. En aquella situación quien manda en el barco es el capitán y el monarca debe abedecer. El principio de The Tempest es como un resumen de todas las posibles formas de iniciar una acción dramática. Shakespeare sabe colocar el poder, tantas veces representado por un rey, y su "antagonista" enfrentados ya desde los primeros momentos. Apenas se inicia la acción, desde muy pronto ya sabemos que ese monarca tiene un conflicto que pesa sobre él. Otras veces desde las primeras escenas se plantea lo que será el nudo de toda la obra. Shakespeare tuvo prisa en hacer de sus primeros momentos instantes reveladores y dar pronto la clave del desarrollo de toda la acción posterior. Si repasamos todas sus obras encontramos todos los principios imaginables, incluso un barco en plena tempestad. No tendría sentido-aunque se podría-hacer una estadística de número de personas que aparecen, forma de hablar entre ellas, relación de preguntas-respuestas y hasta líneas concedidas a cada héroe. $\mathrm{Si}$, en cambio, puede ser interesante intentar algunas observaciones para sacar conclusiones de cómo Shakespeare iniciaba su "narración". Cómo era su "En un lugar de La Mancha de cuyo nombre no quiero acordarme" y su "Call me Ishmael". Esos primeros momentos van a ser tantas veces el emblema de todo el desarrollo posterior.

Una primera división, muy obvia, podía ser entre las obras que se inician en un espacio abierto y uno cerrado, resultado una relación de 19 a 14 . Pero avanzando un poco más y siguiendo con la primera posibilidad advertiríamos ya que por lo menos cuatro obras Love's Labour's Lost, As You Like It, The 
Taming of the Shrew y Cymbeline desde su primera escena nos dejan ver un espacio vegetal. Seis se abren en calles, Coriolanus, Othello, The Merchant of Venice (que también puede ser un muelle), Richard III, Julius Caesar y The Two Gentlemen of Verona. Romeo and Juliet, tras un coro, nos muestra una plaza. Seis se inician delante de una edificación notable, palacio, castillo, incluso vivienda: Hamlet, bien que estamos en el "guard platform" del castillo, Titus Andronicus, The Merry Wives of Windsor, Much Ado About Nothing, Pericles, o, tras el prólogo, Troilus and Cressida. Macbeth tras la escena de las brujas nos muestra en el campo al Rey Duncan. The Tempest se abre en pleno mar. Todas estas variantes del "open space" nos hacen observar que estamos ante dos grandes tendencias la de situarnos en una calle que se equipara en número con la de colocarnos ante una casa que tiene un valor definidor en la obra. Después vendrían los "principios vegetales", para dejar paso al final, con una sola mención a la singularidad de la plaza de Verona-Romeo and Juliet, las brujas en el campo devastado Macbeth y el mar encolerizado The Tempest. Pero avancemos un poco más en este análisis de los principios al "aire libre".

¿Por qué quiso Shakespeare que las obras A, B, C y D empezasen en un marco vegetal? ¿Por qué en cambio propuso para las E, F, G... un arranque ciudadano y la esplícita mención a una calle? ¿Por qué la obra $\mathrm{H}$ se abre en el mar? Son preguntas de muy difícil o imposible-solución y no caeremos en la falacia de intentar "ver qué tienen de común A, B, C y D" para sacar una forzada consecuencia y de ahí una discutible teoria. Lo que sí se puede intentar observar es algún dato curioso. La calle es símbolo de vida cotidiana y está alejada del concepto palacio, y puede ser para Shakespeare el lugar de la "vox populi", del rumor y del bulo. Y es muy curioso que entre las seis obras que se abren en este lugar, sólo hay una Richard III con una figura regia, en dos de ellas Coriolanus y Julius Caesar hablan ciudadanos. En Othello asistimos a una conversación entre Roderigo y Iago, en The Merchant of Venice Antonio nos cuenta su melancolía y en The Two Gentleman of Verona dos amigos discuten animados. La "figura central", incluso la que da nombre a la obra, ha aparecido ya desde el principio en la calle en Richard III, Merchant of Venice y The Two Gentlemen of Verona. Las otras seis que se abren "delante de" solo conceden que aparezca el héroe central en Troilus and Cressida donde el príncipe enamorado hablá "before Priamus's palace". Las cinco restantes ofrecen gamas diversas, aunque conviene que advirtamos cómo en Much Ado About Nothing, "before Leonato's house" empieza a hablar el Gobernador de Messina, Leonato. E1 poder abre la obra, como en los dos Ricardos. La primera palabra la dice quien manda. El bosque o jardín nos advertirá como el Rey abre la acción en Love's Labour's Lost y 'dos caballeros discuten en Cymbeline-motivo que nos lleva a dos obras antes citadas, en "the garden of Cymbeline's palace". Los Capuletos inician la contienda en la historia de Romeo y Julieta, en una plaza de Verona. Pasadas las brujas será el Rey Duncan quier habla en Macbeth.

El análisis de estas situaciones nos lleva a pensar que hemos establecido 
unos datos de los que no es posible sacar más teoría que la peculiaridad de algunos casos singulares. Shakespeare se escapa de todo modelo, es imposible atraparlo. Si nos acercamos ahora a los "espacios interiores" tendremos que convenir que hay un orden muy distinto al anterior. De los 14 casos reseñados en esta situación 12 son de palacio. Sospechamos entonces que para Shakespeare el concepto "interior" era casi sinónimo de grandeza noble, mientras que hay dos restantes que tienen lugar en distintos ámbitos. Timon of Athens en su propia casa, tal vez lo podríamos incluir en palacio y Henry $V I$ en sus tres partes nos lleva la primera a Westminster y un funeral, la segunda a un palacio en Londres donde el Duke de Suffolk va a hablar, y la tercera al Parlamento donde entra el Duque de York. También podríamos pesar en las diferencias incluirlas en el apartado anterior y convenir en que estamos ante una norma con suficientes casos repetidos. Todas estas obras, aparte de las dos citadas con las salvedades hechas, se abren en palacios; The Comedy of Errors, Twelfth Night, All's Well That Ends Well, tras el coro Henry $V$, el primer Henry $I V$, ya que el segundo tras el rumor se abre el castillo de Northumberland, King John, Antony and Cleopatra, Richard II, Measure for Measure, The Winter's Tale, MidsummersNight's Dream y finalmente King Lear.

Esta incidencia en lo regio sobre lo humilde -imaginemos una obra histórica que se abriese con una conversación dolorida de los soldados- nos hace pensar que estamos ante un dilema que ya desde sus primeros simbolos debe solventarse. Ya dentro del palacio habla por vez primera el rey (u otro símbolo del poder, Duque, etc...) en las siguientes obras; Richard II para solventar una diatriba, el Duque de Illiria Orsino en Twelfht Night y su apología de la música, en Henry IV y en su parte primera Bollingbroke intenta dejar de serlo y habla con dolor al público, igualmente habla el monarca en King John, y el Duque lo hace en Measure for Measure. En Midsummer's Night's Dream Teseo habla con su amada Hipólita. En las restantes obras de arranque interior son otros personajes los que dan la primera información dramática. Meditemos cómo King Lear que pudo haber empezado con el rey anunciando su decisión se resuelve con un diálogo entre el Duque de Kent y el Conde de Gloucester, y ese arranque criptico "I thought the King had more affected the Duke of Albany than Cornwall" que ya nos coloca ante el tema simbólico de las preferencias, que interrumpe Edmund el hijo bastardo del Conde de Gloucester para así dejar paso, como si fuera un preámbulo grandioso a la entrada del Rey, que lo hace junto a los Duques de Albany y Cornwall y sus tres hijas.

Los datos que poseemos sobre este punto de partida de las obras de Shakespeare son básicamente los expuestos, pero conviene ahora hacer un análisis de las distintas situaciones que provocan, el lenguaje utilizado así como la teoría escénica que encubren. Ese arranque debe llevar a un "poner en marcha" unos sucesos por eso ya desde ese momento se tiene que descubrir cuál va a ser el centro del problema. Cuando un monarca aparece ante los espectadores ha habido un auténtico "milagro". El hecho de que Ricardo II se nos muestre como un artífice de la justicia nos lleva a considerar que estamos ante 


\section{CANDIDO PEREZ GALLEGO}

toda una teoría de la restauración moral que E.M.W. Tillyard ve así: "Of all Shakespeare's plays Richard II is the most formal and ceremonial, it is not only that Richard himself is a true king in appearance, in his command of the trappings of royalty. While being deficient in the solid virtues of the ruler; that is a commonplace: the ceremonial character of the play extends much wider than Richard's own nature or the exquisite patterns of his poetic speech"1 idea que nos remite a la sospecha de que ese duelo verbal que ante el rey va a desarrollarse necesita una inmediata justificación. Será el Rey quien aparezca, como en su continuación Henry IV el asesino del monarca anterior. Estamos así en una cadena de acontecimientos que nos van hilvanado las "escenas primeras" como si fueran una consecuencia de la última de la obra histórica previa. Tenemos la sensación de que el final de Richard II genera el arranque de Henry $I V$, o que el final de Henry VI provoca el de Richard III, del mismo modo que Henry $V$ era una obra que produciría su seguidora. Muerte y funeral se hermanan.

Este punto reclama otro. La apertura a la acción dramática se realiza de modos muy variados. En Hamlet el eje central del tema, la muerte del Rey ocurrió antes de empezar la obra y todo el drama es como una representación de aquella. En The Winter's Tale la amistad entre Leontes y Polixenes viene desde años juveniles. En The Tempest lo que le ocurrió a Prospero y a su hija antes se va a contar después. Esto nos llevaría a la creación de un Proto-Shakespeare, donde viéramos la boda del Rey Lear y su posterior viudez, a Macbeth de niño e incluso los años de lealtad de Bollinbroke hacia su primo en épocas pretéritas: este culto a la nostalgia es ya novela, es el "temp perdu" que nos muestra la niñez de Hamlet donde albergó sus primeros impulsos de desconfianza hacia su madre y lo mismo nos señala el asombro de un padre-Twelfth Night- que tuvo dos gemelos niño y niña y les puso de nombre Sebastián y Viola. Esa zona de indefinible belleza, la hermosa sensación de que antes del teatro hay novela nos está demostrando que lo que vemos ahora en el escenario y que surge en este ahora, es ya consecuencia del illo tempore que lo potencia así como darnos cuenta de que en las primeras escenas es donde se debe dar la mayor información sobre los rasgos generales del héroe. Cierto que sabemos mejor cómo es Laertes al final que al principio, y de aquí que sus primeras apariciones sean las que dibujen lo esencial. Por esa misma razón los grandes paradigmas "si hay crimen hay venganza" "si hay belleza puede perderse" "si hay poder hay conspiración" deben de insinuarse desde los momentos iniciales hasta el extremo de que toda una dinámica de hechos lleve a considerar que el "matar a Duncan" se venía forjando desde el principio lo mismo que el casar a Portia lo sabemos desde muy pronto. Estamos ante un mecanismo de condensación, de irrupción de la teoría de los hechos en un "conductismo" moral que nos hace establecer unos códigos muy estrictos donde poder movernos con

1 Shakespeare's History Plays by E.M.W. Tillyard Harmondsworth: Penguin Books, 1962 (1944) pp. 245/246. 
facilidad. El hermoso rebirth de las últimas obras ha de ser posterior a un temprano perder. El perdón ha de ser posterior a la ofensa. La derrota ocurre tras la contienda. Esta es la hermeneútica de unos hechos que descubren un horizonte nuevo y lo abren para darnos hermosas posibilidades de análisis. Y en este punto es donde hemos de ver, por ejemplo, qué lugar ocupan en la estructura de la obra los reyes (Alonso, Lear, Hamlet, Duncan, Ricardo II, Enrique $\mathrm{V}$, etc...), cuál los poderosos (Orsino, Vicentio, Teseo,...), en que posición encontramos a los príncipes (Hamlet, Troilus, Hall, Ferdinand...) dónde tenemos a los asesinos (Bollingbroke-Exton, Macbeth, Cloucester, Brutus...). Este cuadro nos daría un mapa de la obra y ver la dinámica de sus roles y hasta la manera de moverse por las escenas de acuerdo a su función. Esta es la dinámica dramática y en la escena primera están los gérmenes.

La escena primera, además de colocarnos en la situación inicial, nos remite a la segunda que tiene que ser como un contrapunto. Basten tres ejemplos. En The Tempest el momento del naufragio sigue por una bellísima visión "before Prospero's cell" - que nos llevaría a "delante del palacio"- donde Miranda inicia uno de los más hermosos discursos de todo Shakespeare; "If by your art, my dearest father, you have/Put the wild waters in this roar, allay them" $(I, 2)$ que es como una dulce melodía de paz tras el estrépito desesperado de los marinos ahogándose. The Merchant of Venice contrasta el arranque con Antonio y sus amigos a la paz de Belmont donde Portia habla con Nerissa. Hamlet deja paso de la escena de pavor ante la llegada del "ghost" a otra donde el nuevo rey Claudius y toda la corte se duele, y propone "to bear our hears in grief" $(I, 2)$. Significa este dato que a nuestro dramaturgo le gusta contrastar entre escenas para mantener la atención y así hay una tendencia a que entre la primera y la segunda exista un cambio de lugar y espacio escénico, así como surjan a poder ser los componentes "de la otra parte del relato". Este arte de contrastes viene expuesto en nuestra Dramática de Shakespeare ${ }^{2}$ donde advertimos como en su escenario se trata de hacer enfrentamientos horizontales nunca verticales queda dividido entre espacios del protagonista y del antagonista.

Sirva de ejemplo Henry IV con el mundo del rey contrapuesto al de Falstaff y con la figura del Príncipe Hall yendo y viniendo de uno a otro. Como opina con talento Lily B. Campbell; "As the first part of Henry $I V$ deals with the rebellion organized to overthrow the king, so the second part shows the disintegration of the rebellion. As the first part of Henry IV shows a wastrel son, who was to his father a part of God's revenge, finally acquiring honor at Shrewsbury, so the second part shows the father and son throwing off his unfit

2 "Dentro-fuera en teatro" en Dramática de Shakespeare por Cándido Pérez Gállego. Zaragoza; Pórtico, 1974 pp. 275/308. En su memoria de licenciatura Luisa Gavasa analiza este punto referido a Macbeth; "Si en Macbeth hay un personaje al que se nombra y no aparece (nos referinos a King Edward the Confessor) en Hamlet se habla a menudo de Fortinbras pero con la diferencia de que éste aparecerá dos veces en el transcurso de la acción". La destrucción en "Macbeth" por Luisa Gavasa. Zaragoza: Universidad, Memoria de licenciatura, 1978, p. 14 


\section{CANDIDO PEREZ GALLEGO}

companions and taking upon him the virtues of a king as though virtue were easily put on as a new garment"3. Esta idea de cambio debe ya sugerirse desde el comienzo y la tesis de una obra de Shakespeare presentará desde sus orígenes un plan concreto de búsqueda de una argumentación moral. Se trata de restituir, de cambiar y debemos conocer todas las normas de ese proceso, lo mismo sea Hall bajo Falstaff, como el rey Alonso bajo el contramaestre. Hay una eventual "ruptura del orden" que nos lleva a que el esquema familiar padres/ hijos se vaya deteriorando con la aparición de unos elementos perturbadores que intentarán desequilibrar ese esquema. Las coaliciones proliferan, las uniones se van dibujando y así llegamos a una "catharsis" donde evidenciemos que un argumento ha concluido. Este es el esquema que tantas veces va a repetirse; orden-caos-orden que lo mismo nos remite a Macbeth como a Measure for Measure.

Esta investigación sobre la dinámica escénica nos está abriendo más horizontes. Incluso temas como los límites de la imagináciớn, lâ relación entre apariencia $\mathrm{y}$ realidad o la búsqueda del perdón tienen su estructura actuante, un lugar adecuado y esa tendencia a que palacio-jardín ocupen la "interioridad" del proceso nos excluye unos espacios que tendrán que ir apareciendo lógicamente -y asi sucederá- a lo largo de la obra. Bassanio en The Merchant of Venice como nuevo Jason hace un viaje a Portia. El Duque de Viena tras su regreso da una lección de ética cristiana. Entre los actos tercero y cuarto de Pericles transcurren catorce años. Lear lleva enloquecido el cadaver de Cordelia en sus brazos... estas actuaciones tienen un origen en unos hechos ocurridos mucho antes y la dialéctica de la praxis teatral necesita que sepamos cómo se ha llegado a esta situación y alcanzado este punto de tensión. Hemos de retroceder y buscar un punto de partida; este es el experimento que Shakespeare nos brinda de modo insistente, rastrear en el pasado las motivaciones del presente. Analizar "lo que hicieron antes", lo mismo Ricardo II, como Leontes o Desdémona, instaurar en el escenario un proceso lógico que señala a una construcción coherente, de modo que todo extracto que hagamos en la obra tenga un antes y un después.

¿Dónde está el "antes" del principio de la obra" ¿Qué ocurrió antes de que el mar se enloqueciera en The Tempest? La búsqueda de esta novela -antes la hemos definido así- nos está dando ocasión a hablar de una "peripecia" como giro de la acción, pero también a sospechar que ya desde el arranque se van proponiendo los dilemas donde reposa y va a colocarse todo el sistema expresivo posterior. La obra se hará "comedy or errors" y deberemos entrar en ese punto de partida como si hubiera sido un momento elegido de manera que nos informe de la mayor cantidad posible de datos. Si el final feliz era la recompensa de las comedias - lo hemos visto en Shakespeare y la politica ${ }^{4}$ - el arranque feliz

3 Shakespeare's Histories by Lily B. Campbell, London; Methuen, 1964

(1947) p.p.224.

4 "La Monarquía patrocinadora del final feliz" en Shakespeare y la politica 
tiene que prevenir de que algo malo va a ocurrir, la conspiración acecha y hay un orden vigilante que recela de ese emblema de paz universal que pretende instaurarse. Ricardo II será feliz muy poco tiempo, como Hamlet o el Rey Lear. Son seres que viven con intensidad el tiempo que les vemos actuar y pronto se abre contra ellos una conspiración que será el resultado de las tensiones que la adversidad ha preparado. Ese "antes" es una época donde se forjaron los comportamientos del "ahora", y cuando Shakesperare abre su escena lo hace a sabiendas de que ha elegido el momento de más tensión, el instante de mayor acumulación de datos definidores. Abre en el instante justo, en el mismo momento en el que un viejo rey decide preguntar a sus hijas si le quieren. Este es el talento de esta elección, el saber empezar la acción dramática donde y cuando hay que empezarla.

Incluso en las comedas este ceremonial se produce. Tomemos Twelfth Night como ejemplo y veamos cómo el disfraz de Viola al convertirse en Sebastián es un truco necesario para alcanzar un final feliz que era importante conseguir. Como muy bien observa John Dover Wilson: "Orsino is the sentimentalist in love with Love. He has steeped himself, we may imagine, in Petrarch; he prefers worshipping at a distance, and wooing by proxy; he likes to stab himself with the thought of the cruelty of his adored. It is not Olivia's person he desires, he readily makes shift with Viola at the end, when Olivia proves to be the bride of another. It is the dream of her that fills him with melancholy satisfaction. Viola will make him a good wife, because she wants him and is the soul of loyalty and devotion"5 idea donde nos colocamos ante esa base que toda obra tiene, ese punto de partida sólido, que se va cambiando dirigiéndose al "no es como imaginábamos", a sacarnos del error/real que la primera escena nos entregaba. Lo que ahora vemos, unas hijas que dicen amar a su padre, es falso y en verdad le odian a muerte. No es cierto que el Rey Claudio este muy triste por la muerte de su hermano sino que él mismo le ha mandado matar. El amor de Orsino por Olivia no es tan sólido como parecía y esta bella muchacha que viene de los mares lo va a romper. Principio sería entonces crítica al sistema, análisis de lo entregado para asi promover otra situación de características diferentes. Es el arranque también de un proceso de modificación, de ir viendo cómo los acontecimientos se van moviendo hacia un punto que al principio ignorábamos.

¿Como imaginar el final de Ricardo II o del Rey Duncan? ¿Es que se puede pensar que esa amistad entrañable entre Polixenes y Leontes termine en una "resurección"? ¿Debemos admitir que el Troilus del principio y el del final es el mismo? Estas preguntas nos empujan a la misma esencia del hecho dramático pero sobre todo a una particular forma de dinamizar los hechos que Shakespeare sabe imponer a la perfección a sus situaciones: se nos coloca entonces

por Cándido Pérez Gállego, Madrid: Narcea, 1971 pp. 44/60. Esta imagen del final feliz nos obligaría a una nueva consideración de la doctrina de Anatomy of Criticism, llevándola todo lo posible a un plano social que por cierto $\mathrm{N}$. Frye elude.

5 Shakespeare's Happy Comedies by John Dover Wilson, London; Faber and Faber, 1967 p. 169. 
ante su misma razón de ser. En el arranque de Love's Labour's Lost encontramos en las palabras del Rey ocasión de ver lo que un cambio puede significar inmediatamente. Justamente va a ocurrir que el amor rompe la armonía de la academia, que entre la pasión en sus vidas. Muy bien lo ha visto E.M.W. Tillyard: "The reference to death was quite hollow, for real death was the last thing that Navarre had in his mind; and in the body of the play he and his fellow live in the moment, as regardless of the future as any young men have ever been. The irruption of real and present death into their moods of greatest frivolity shakes them to their depths; they will not be the same men after it"6. Esta imagen de alusión prematura a la muerte será la que cierre la obra con una muerte real que condiciona esa aventura de amor recién iniciada.

Este punto nos remite a G. Wilson Knight y su delicioso ensayo sobre "The Phoenix and the Turtle": "Love is not simply "the love of the beautiful" but rather it aims, even when it is not obviously biological, at "generation and production in the beautiful", because "generation is something eternal and immortal in mortality". Love can accordingly be regarded as "the desire of immortality". Socrates' statement is the more valuable since it is not a stament of the supreme beauty alone, but exist rather, as do all our Phoenix symbolism, at the meeting-place of time and eternity" ", idea que una vez aceptada nos haría pensar que la escena inicial en el teatro de Shakespeare, cambia por una distinta observación de las relaciones humanas, una reconsideración de los efectos y hasta una distinta visión del modo de entender las vinculaciones de los nexos familiares. Este proceso de cambio nos está devolviendo la esperanza de que haya toda una meditación autocrítica en los primeros momentos de cada drama. Y este dato lo podemos observar lo mismo en Henry IV como en The Winter's Tale, igual en Henry $V$ como en Richard $I I I^{8}$.

Entramos entonces en un análisis de lo dicho en el principio en relación con sus consecuencias posteriores o como la palabra lleva a la praxis y entramos por tanto en un territorio donde el modelo narrativo sea causa de acciones que nos den la verdadera imagen "de lo que está ocurriendo". Tal énfasis de lo que inicia la acción sobre lo posterior nos llevaría a toda una teoría de la modelación de un espacio inicial, el $(I, 1)$ que es como el mecanismo que pone en marcha toda una serie de motivaciones que tienden a romper el esquema "A hizo X con B" que ya analizábamos en Sintaxis Social ${ }^{9}$ y hasta

6 Shakespeare's Early Comedies by E.M.W. Tillyard, London; Chatto and Windus, 1966 p. 176.

7 The Mutual Flame by G. Wilson Knight, London; Methuen, 1978 (1955) p. 216. Debo d la Dra. Luisa Capecchi ideas muy importantes para entender el sentido del diálogo amoroso en Petrarca, que creemos punto de partida de muchas de las actitudes afectivas de Shakespeare.

8 Vid en este punto "Shakespeare and the Medieval Ethic" by L.A. Cormican, Cambridge; Scrutiny, march 1951 pp. 298/317.

9 Sintaxis Social por Cándido Pérez Gállego, Madrid; Fundamentos, 1977, pp. 153/241. 
pensar que el teatro es un experimento de modificación a la vista del público donde los espectadores cambian su actitud de acuerdo a unas nuevas informaciones que van entrando en el escenario. Este es el secreto que mueve Henry IV donde nos vamos a encontrar ante una teoría del poder-injustamente obtenidoenfrentada con la misma insurrección de un hijo que ha encontrado un nuevo padre. Pensar que el dilema de enfrentamiento entre dos personas sea el punto de partida de toda la dramática de Shakespeare puede no siempre cumplirse, aunque en muchas ocasiones sea válido. Nos encontramos ahora ante el verdadero centro de nuestra discusión. ¿A dónde nos llevan esas primeras palabras? ¿A quién convencen? ¿Qué modifican? Veamos si es posible descifrarlo aproximándonos a unos ejemplos que nos den datos sobre este punto. El teatro es la ciencia expresiva del gesto y la palabra, y la textualidad cumple una misión básica al no poder venir refrendada por la omnisciencia de un novelista que explica incluso lo que ocurre en el fondo del corazón. En teatro todo debe ser visto $\mathrm{u}$ oido. Entremos en este punto con un mayor detalle ${ }^{10}$.

La gran obra de la reconciliación entre padre e hijo es Henry $I V$ y en ella asistimos a un proceso de desplazamiento de Falstaff que en la escena última tiene papel básico. Cuando éste drama se abre lo hace con uno de los más hermosos parlamentos de todo Shakespeare. Entra el Rey Enrique con Sir Walter Blunt para encontrar a Westmoreland y acompañantes. Estamos en Londres $\mathrm{y}$ en su palacio. Respetemos este arranque en su disposición inicial: Habla el que hasta hace poco era Bollingbroke:

"So shaken as we are, so wan with care, Find we a time for frighted peace to pant, And breathe short-winded accents of new broils

To be commenced in strands afar remote:

No more the thirsty entrance of this soil

Shall daub her lips with her own children's blood,

Nor bruise her flowerets with the armed hoofs

Of hostile paces: those opposed eyes,

Which, like the meteors of a troubled heaven,

All of one nature, of one substance bred,

Did lately meet in the intestine shock

And furious close of civil butchery,

Shall now, in mutual well-beseeming ranks, March all one way, and be no more opposed

Against acquaintance, kindred, and allies..."

Este modo de hablar del rey es uno de los más bellos símbolos del deseo de

10 Vid para entender mejor este problema: "The Nature of Plot in Drama" by EllisFermor en: London; Essays and Studies, 1961, Murray pp. 65/81. 


\section{CANDIDO PEREZ GALLEGO}

iniciar una vita nouva. Parece que el fantasma de Ricardo II le persigue y hasta nos encontramos con una bellísima metáfora del buscar un horizonte donde ese proyectado viaje a Tierra Santa sea la meta. La parte segunda de Henry IV nos dará un principio inesperado; "Warkworth. Before the gate of Northumberland's castle. Induction. Enter Rumour, painted full of tongues", que nos va a remitir cuando el "Tiempo" aparezca en The Winters's Tale. Shakespeare ya no da sólo importancia a la palabra expresada directamente sino que incluye el rumor como elemento discursivo. Oigamoslo:

"Open your ears; for which of you will stop

The vent of hearing when loud Rumour speaks?

I from the orient to the drooping west,

Making the wind my post-horse, still unfold

The acts commencéd on this ball of earth.

Upon my tongues continual slanders ride,

The which in every language I pronounce,

Stuffing the ears of men with false reports.

I speak of peace while convert enmity

Under the smile of safety wounds the world:

And, who but Rumour, who but only I,

Make fearful musters and prepared defence,

Whiles the big year, swoln with some other grief,

Is though with child by the stern tyrant war,

And no such matter? Rumour is a pipe

Blown by surmises, jealousies, conjectures,

And of so easy amd so plain a stop

That the blunt monster with uncounted heads,

The still-discordant wav'ring multitude,

Can play upon it... But what need I thus

My well-Known body to anamotize

Among my household? Why is Rumour hee?"

Estas palabras nos remiten a la necesidad de justificar una presencia y nos llevan a la misión de ese rumor vegetal que los jardineros de Richard II nos mostraban. Estamos en ei preámbulo de un proceso que llenará por completo el escenario y las palabras se deben dispersar como si estuviesen lanzadas en todas las direcciones.

Henry $V$ nos ofrece un "coro" que ironiza sobre la dimensión del teatro "Can this cockpit hold/The vasty fields of France? Or may we cram/Within this woodden $O$ the very casques/ That did affright the air at Agincourt?" (I,1) que es una genial advertencia a cómo se va a desarrollar una acción que supera los límites del espacio teatral. Henry $V I$, en su parte primera, se abre solemnemente en la abadía de Westmster y en el funeral del rey Enrique V. Bedford abre la acción: 
"Hung be the heavens with black, yield day to night!

Comets, importing change of times and states,

Brandish your crystal tresses in the sky,

And with them scourge the bad revolting stars

That have consented unto Henry's death!

King Henry the Fifth, too famous to live long!

England ne'er lost a king of so much worth"

que es el más hermoso preámbulo a una acción violenta que se vislumbra. En su segunda parte estamos en Londres y Suffolk arrodillado ante el rey le informa de su misiva:

"As by your imperial majesty

I had in charge at my depart for France,

As procurator to your excellence,

To marry Princess Margaret for your grace,

So, in the famous ancient city Tours,

In presence of the Kings of France and Sicil,

The Dukes of Orleans, Calaber, Bretagne and Allençon,

Seven Earls, twelve barons and twenty rebered bishops,

I have performed my task and was espoused,

And humbly now upon my bended knee,

In sight of England and her lordly peers,

Deliver up my title in the queen

To your gracious hands, that are the substance

Of that great shadow I did represent,"”

palabras que llevan a invitar al hablante al levantarse. El rey inicia su cometido y una invisible decadencia se cierne sobre sus palabras.

La parte tercera de Henry $V I$ ya parece, desde su comienzo, prevenir del trágico marco que le acompaña. Estamos en Londres, en el Parlamento y la aparición de los seguidores de las rosas blancas surgen, rodeando al Duke de York. La primera frase es reveladora, y brota de labios de Warwick: "I wonder how the king escaped our hands" (I,1) que ya nos pone en presencia de una acción de búsqueda y captura que York simboliza. El cierre es, ya lo sabemos, Richard III y las intenciones de Gloucester se abren al público, como en The Jew of Malta lo hacia Maquiavelo. Oigamos ese parlamento, que tiene lugar en una calle de Londres:

"Now is the winter of our discontent

Made glorious summer by this sun of York;

And all the clouds that lour'd upon our house 


\section{CANDIDO PEREZ GALLEGO}

In the deep bosom of the ocean buried"

(...) $(\mathbf{I}, 1)$

que es el final de un proceso que lleva indefectiblemente a Bosworth. Estamos ante el tema de la caída del tirano, como Northrop y Frye muestra en Fools of Time Ti $^{11}$ y nos encontramos en un mecanismo de restitución imposible que nos hace ver en la sucesión de tragedias históricas una muestra del hundimiento humano. Igual que Hamlet se ve obligado a actuar y pasa del nivel dialéctico al de la praxis lo mismo en las "historias" existe el peso de un nivel de conspiración que se abre para desencadenar la maldad. La imagen adversa de Cloucester no es la de Bollingbroke sino que tiene un fatalismo mucho mayor, llevándonos a la catharsis que se impone en Macbeth una vez que el Rey Duncan es asesinado. El planteamiento es pues de centrar la tragedia en el poder, en un monarca, y asumirlo desde el principio alejándonos ahora incluso de la cobardía de Troilus cuando se niegue a luchar fuera de las murallas de Troya cuando en su corazón enamorado tiene ya tan cruel batalla.

Este gesto nos debe hacer reflexionar en el tono de confesión que en Troilus encontramos que es del mismo nivel de confidencia -aunque de tan distintas intenciones- que el de futuro Ricardo III. La ceremonia inmediata de deposición que alcanza lo mismo a Ricardo III. La ceremonia inmediata de deposición que alcanza lo mismo a Ricardo II como al Rey Lear nos advierte de que hay en Shakespeare un orden de alejamiento de la Golden Age y de inmersión en los sucesos más luctuosos de la época. Las comedias quedan ahora lejos y nos colocamos en un punto de tensión carismática-Ricardo II es el mejor ejemplo- que nos señala los milagros que Próspero hace en The Tempest. Desde este punto de vista la dinámica de las actuaciones - que ya en el principio se muestra bien visible - es prueba de que el "ideal ruler" esta siendo observado con desconfianza. Su muerte es deseada por alguien del escenario, y la caída de Julio Cesar, Rey Hamlet o del Rey Lear acarrean uno derrumbamiento total del espacio donde esa acción se desarrolla. Estamos ante una metáfora de ascenso/ caida, que Marlowe ya muestra y ante un mito de rebirth que el Príncipe Hall va a escarnar como adelantándose a los "romances". Mundos enfrentados, clanes er punta, familias enemistadas es la dinámica social donde un rey habla con el público y pide condescendencia.

11 "There are, two symbolic aspects of the ruler, or what we have been calling the orderfigure, in Shakespeare's tragedy. There is the deposed or murdered ruler, Caesar, Duncan, Hamlet's father, Richard II, the abdicating Lear, who, as that, represents a lost social identity; we shall not look upon his like again, or the like of what he stood for. His archetype is neither Apollo nor Dionysus, but Keat's hero Hyperion, the father of the sun-god, to whom Hamlet's father is twice compared. The other is the ruler conceived as actual ruler, the successful strong man, Octavius, Henry V, Henry VIII, and Julius Caesar for the first two acts of his play. Such a figure is both Apollo and Dionysus, lord of both the order of nature and the heroic energy of fortune. The leader controls a world where reality is also appearance, and therefore illusion, as well as reality" Fools of Time by Northrop Frye, Lond on; Oxford University Press, 1967 p. 37. 
Hablemos, entonces de un principio cómico y otro trágico, un punto de partida que lleva al "final feliz" ya desde los primeros momentos y otro que señala a Death como si se tratara de una Morality. Y en esta dualidad, las comedias son la prueba de que Shakespeare dudaba de su mecanismo de proyección y se abría en un horizonte donde "recuperar lo perdido", emblema por cierto de los romances últimos, sería como un símbolo imposible de abandonar. El héroe cómico cambia de identidad, finge, lucha y al final consigue una meta. Este dato lo vemos lo mismo en As You Like It como en The Comedy of Errors mientras que en Hamlet, por citar un ejemplo, hasta la mínima escena está orientada a demostrar como hay un orden que se tambalea, una profundidad moral que se abre para dejar paso a una nada que intenta superarse. Estamos, pues, en un territorio de reticencias simbólicas que Wolfgang Clemen ha estudiado con esmero: "In Hamlet, in Lear and in other great tragedies the puns frequently are important clues and connecting links in the structure of the dramatic action. The ambiguous image which plays such a large part in the tragedies grows out of the play on words. With deep irony Shakespeare often lets the ambiguity of the world shine through the ambiguity of the metaphor"12 y aqui tenemos algo muy importante que conviene que no se nos olvide y es que la manera de construir un mundo metafórico en Shakespeare condiciona la praxis de sus héroes. El hecho de que la metáfora del arranque inicial sea una prueba de "participación en el argumento" es revelador y nos da ocasión a abrir un horizonte donde las palabras de por sí marquen un camino más y más nítido.

Las comedias lo van a demostrar. El deseo de que la ambiguedad se rompa y de que lo separado se una, nos está dejando pruebas evidentes de que hay un mundo de conversiones que nos persigue y que hace que veamos, por ejemplo, Measure for Measure como ejemplo claro de una definición ética que ya en el principio va a tener dimensiones de "tautología". Lo que se quiere demostrar hay que hacerlo desde el principio y es necesario que ya en las primeras escenas se nos abra la expresión escénica para provocar un planteamiento de los distintos niveles dramáticos. El poder surge, la amistad aparece, el rumor se alza... y dan paso a una separación entre lo social y lo familiar que señala la necesidad de un nexo afectivo que muy pronto va a aparecer como prueba palpable de una manera especial de integrar la ambigüedad en la metáfora sólida a la que antes Wolfgang Clemen hacía una cuidada referencia. Con tales datos se nos puede producir una confusión de las intenciones del autor que en The Tempest son obvias desde el principio pero en Twelfth Nitght resultan mucho más críticas y hasta colocarnos en un punto de integración de la palabra en su componente más obvio. Aquí es donde el Duque de Viena puede hablar y tiene a su alrededor el boato - la pantalla - adecuada. Se dirige al público como lo haría Ricardo II o Ricardo III. Hemos descubierto como hay un principio ordenador del poder que en muchas obras será más emblema que símbolo.

12 The Development of Shakespeare's Imagery by Wolfgang Clemen, London: Methuen, 1977 (1951) p. 33. 


\section{CANDIDO PEREZ GALLEGO}

Sus comedias nos llevan a más consideraciones. The Two Gentlemen of Verona se abre en un "open place" de Verona, "a street near Julia's house; trees ans seat" donde Valentine se despide de Proteus para ver "the wonders of the world abroad" $(I, 1)$ y de ese modo el "loving Proteus" queda distanciado del "sweet Valentine". The Merry Wives of Windsor se inicia ante la casa de Page y Shalow toma la palabra. Measure for Measure, como Richard II, surge con el poder y "The concil-chamber in the Duke's palace at Viena". E1 Duque Vincentio llama su "ancient lord" Escalus y después a Angelo iniciándose así la diatriba moral. The Comedy of Errors nos muestra "a public square in Ephesus, hard by the Mart: in the centre, at the sign of the Phoenix, the house of Antipholus of Ephesus, with a balcony; on one side, the wall of an abbeygarden, with a gate; on the other the entrance to a street. Without the gardenwall stands a judgement-seat of stone, with steps leading thereto" para dejar paso al Duque de Efeso que habla con el mercader de Siracusa Aegeon. Much Ado About Nothing nos deja ver "An orchard, adjoining the house of Leonato; at one side a convered alley of thick-plaeched fruittrees; at the back an arbour overgrown with honeysuckle" y el Gobernador de Messina, Leonato inicia la acción para advertir que un príncipe aragonés llegará por la noche a la ciudad. Love's Labour's Lost tiene un arranque vegetal y un Rey de Navarra con sus señores, Berowne, Longaville y Dumain, recuerda como deben ser "heirs of all eternity" y seguir "that war against your own affections" (i.1), viviendo estos "fellow-scholars" apartados del amor.

También el poder abre $A$ Midsummer Night's Dream donde en Atenas, es su duque Teseo quien habla a su amor de la "nuptial hour" (1.1) para decir a Philostrate poco después "Turn melancholy forth to funerals; / The pale companion is not for our pomp" y pronunciar el ambiguo "Hippolyta I woo'd thee with my sword, / And won thy love doing thee injuries," que tiene un obvio sentido sexual. As You Like It en su primera visión del "orchard, near Oliver's house" da lugar a que Orlando hijo de Sir Rowland de Boys se enfrente con el público sonriente y divertido. The Taming of the Shrew tiene una curiosa anomalía en su "induction" -pensamos ahora en The Spanish Trage$d y$-" before an alehouse on a heath" donde Christopher Sly aparece borracho. All's Well That Ends Well nos sitúa en "a room in the palace of Rouisillon" donde sus condes dialogan. Twelfth Night presenta un escenario semejante $y$ ahora es en su palacio donde el Duque de Illiria, Orsino nos cuenta sus problemas mientras unos músicos acompañan. "If music be the food of love, play on" (i, 1) uno de los más bellos momentos de Shakespeare que nos conduce a una situación de hastío y melancolía. Y este tema será el que muestre The Merchant of Venice obra que vamos a analizar con una mayor profundidad. El recorrido por las comedias nos ha dado una configuración dispersa donde alterna el poder con su problema inmediato y donde hay una tendencia a que el tema objeto de la obra se esboce desde muy pronto. Arcadia y palacio van a ser el eje de una movilidad escénica que nos situe la acción como un juego continuo. Este será el maravilloso mundo de las comedias, y J. Dover Wilson 


\section{COMO EMPIEZAN LAS OBRAS DE SHAKESPEARE}

lo ha advertido con detalle ${ }^{13}$ para dejarnos al descubierto sus peculiaridades obvias.

The Merchant of Venice nos ofrece nuevas consideraciones ya que en su primera escena se plantea el problema de Antonio, incluso en su primera frase: "In sooth I know not why I am so sad, /It wearies me, you say it wearies you;" (I,1) donde tenemos cómo la voz dolorida por la melancolía del Mercader de Venecia apoyar en sus amigos Salerio y Solanio que van a tomar la palabra para animarle y llevarle el primero a una lucha contra la imaginación y el segundo a una inmediata acción. Antonio tiene una depresión, se muestra como un neurótico y su amistad con Bassanio, que ahora se aproxima con Lorenzo y Graziano es el contrapunto necesario para entender su psicología. Ha conquistado riquezas, aunque sus barcos están en el mar, se mueve en un ámbito de fantasía y el amor lo da por perdido cuando se lo pregunta Solanio. El motivo de su tristeza no es el dinero y él lo dice "Therefore my merchandise makes me not sad" $(1,1)$ lo cual nos lleva a que veamos en Bassanio su apoyo para salir de la depresión y la acción de este será la que mueve a Antonio fuera de sí. Con la entrada en el escenario de Antonio viene la salida de los dos anteriores, Salerio y Solanio y aunque el amigo fiel viene acompañado de Lorenzo y Graziano, pronto se quedarán solos, en un momento de paz equivalente a los que tengan Hamlet y Horatius. Para Antonio el mundo es como un teatro donde cada cual debe representar un papel siendo el suyo el de la tristeza, casi como un abuelo -según le dice Graciano- para advertirle no intentar buscar en la melancolía una posible reputación. El problema ya está planteado y The Merchant of Venice nos ofrece en su arranque una nueva lectura. Es la historia de una terapia que Bassanio hace a Antonio por medio de lo que el primero querría haber tenido (Portia) y la consecución de una curación simbolizada en los barcos que llegaban a tierra firme. He aquí el eje que desplaza la anécdota de Shylock que sólo sirve para poner de relieve el "valor de la carne", y cuando los dos amigos se encuentran solos se establece entre ambos una auténtica "transferencia". Bassanio está en deuda con Antonio, pero entre ambos se en. trecruza una dama, que no consigue sino sacar a Antonio de su inacción neurótica: el lenguaje de Antonio es de una enorme afectividad, "Then do but say to me what I should do / That in your knowledge may be me be done" $(1,1)$ que es el preámbulo a una auténtica "declaración de amor" uno de los ritmos más bellos de todo Shakespeare. Es la historia de Portia en Belmont, de quien Bassanio nos dice "I did receive fair speechless messages". Antonio ayudará a su amigo a conquistar esta bella y rica-dama. "Money" hace su aparición junto a "Love" y desplaza a "Melancholy" que era como un fantasma que se cernía sobre un horizonte sin esperanzas. Esta es la intención de Antonio, salir de su neurosis, fundirse con la historia de Bassanio y vivir su amor, como lo prueba que al concluir la obra exclame, ya curado, "Sweet lady, you have given me life and living; /For here I read for certain that my ships / Are 


\section{CANDIDO PEREZ GALLEGO}

safely come to road". El testimonio de Portia como agente benéfico nos conduce a un esquema de conversión del caos en orden, como Manuel Angel Conejero pone de relieve ${ }^{14}$. Belmont ha curado la fantasía de Antonio y le ha devuelto a la realidad del Rialto: el mercader ya no está sujeto a su incapacidad de actuar que le atormentaba. Igual que la tristeza de Orsino en Twelfth Night el mercader ha triunfado haciendo que los demás sean felices. La amistad desplaza, en este caso, un proyecto neurótico de individualismo ${ }^{15}$.

Valía la pena ver cómo la enfermedad de Antonio se puede "disolver" en la praxis y esta idea se nos entrega en los primeros minutos de la obra, un esquema donde él ocupa el centro, y su dinero es como el eje de una ambición que necesita Bassanio para ponerse a la altura de su adorada Portia. Los cuatro "inferiores" son como satélites que sirven para matizar o precisar la acción central y sobre todo sacar al héroe central de su "imaginación" y hacerle vivr el problema de Bassanio hasta grados de lealtad absoluta. La belleza rubia de Portia es el centro imposible del amor de Antonio, pero será la recompensa de su dinero, ella está comprada por el oro de Shylock y hasta su hermosura es un emblema ambiguo que surge del plomo. La idea de "no dejarse engañar por las apariencias" será un motivo más de la obra, donde Noryhrop Frye ha descubierto matices profundos ${ }^{16}$. La Arcadia, ámbito vegetal de la rica heredera es lo que le falta a Antonio y lo que Bassanio obtendrá con la carne y dinero de su amigo. Este eje de amor-dinero-carne mueve ese estado depresivo donde Antonio se mueve y que hace de sus barcos surcando los mares un motivo más de irrealidad, como bien advierte E.F.C. Ludowyk, "The play ends happily, with the added impossibility-as it would seem - of the miraculous return of Antonio's ships"17 dato que nos remite a ese juego de ilusiones donde la neurosis de Antonio se desenvuelve. Para A.D. Moody, en cambio, "Antonio's "sadness" is like a keynote sounded before the statement of the play's main concerns. Later, as it persists through the scene, it becomes an undertone set off against and showing up the levity of his friends ${ }^{18}$ idea que llevaría esa melancolía a un punto casi hamletiano, opinión que no comparte la nota correspondiente a la New Shakespeare "The unexplained melancholy on the part of Antonio has been much commented

14 Shakespeare: Orden y caos por Manuel Angel Conejero, Valencia; Fernando Torres, 1975 pp. $15 / 31$.

15 Este dato nos remite a los Sonnets. Sobre ellos el más original y atrevido análisis será tal vez: Shakespeare's Dramatic Meditations by Giorgio Melchiori, Oxford. The Clarendon Press, 1976, 206 pp. (Ver nuestra reseña en Arbor a este libro a aparecer en el número de enero 1979).

16 "Closely allied to this use of music is the suggestion of the supernatural. Ghosts, omens, portents, oracles, magic, withcraft no not enter there to be exhilarating, in the way that they are in romance". Fools of Time by Northrop Frye, op. cit. p. 23.

17 "The Merchant of Venice" by E.F.C. Ludowyk, London; Notes on Literature, n. 110 , sept. 1970, p. 7.

18 Shakespeare. The Merchant of Venice by A.D. Moody, London: Edward Arnold, 1971 (1964) p. 21. 


\section{COMO EMPIEZAN LAS OBRAS DE SHAKESPEARE}

upon by critics"19 y poco después "Is not the secret of his melancholy the fear that this lady may rob him of his dear friend?"20 opinión que coloca los amigos en una situación mucho más inseparable. Portia sería la causa del conflicto emotivo puesto que ella destruye la amistad.

Venecia ocupa el fondo de estos Sonnets, la obra se abre al aire libre, en los muelles de la ciudad ("A quay in Venice. Antonio, Salerio and Solanio approach talking together") que es una forma reposada de iniciar una declaración de principios que muy pronto hace Antonio sobre su "sadness". Con este dato hemos de ver que Shakespeare propuso que ya desde el principio se viera un dato valioso que sin embargo la crítica - centrada en Shylock - ha soslayado. El centro es esta soledad, y la ruptura de la amistad que nos llevaría a los Sonnets y que nos haría ver en The Merchant of Venice una obra de suplantación de funciones. La figura de Portia entrando en el mundo de afecto que dos amigos han forjado y exigiendo su primer tributo: el dinero. Esta forma de mezclar la economía - los tres mil ducados- con la amistad tiene ecos nuevos en Shakespeare y nos produce una sensación penosa. Portia es la causa de la neurosis de Antonio puesto que desplaza a Bassanio de él y a cambio le entrega esa forma de dinero que es la imagen de los barcos recuperados, como en The Tempest.

Las comedias nos han dado la advertencia de que Shakespeare gusta desde el principio plantear sociológicamente una situación escénica. El poder abre la obra con la misma fidelidad que en Richard $I I I$, donde "the winter of our discontent" ha quedado ya como un emblema de un arranque luminoso y genial, mientras que en Troilus and Cressida un "prólogo" hace desde el escenario una función narrativa de lo que va a acaecer, "In Troy, there lies the scene" es una aproximación al ámbito de emociones que Shakespeare nos prepara, como en Henry V ese "coro" que entra recuerda el que surge en Romeo y Juliet. No es todo "brightest heaven of invention", sino que en Richard II habrá sido la imagen regia la que intente solventar una contienda, mientras Juan de Gante observa receloso. Ya no es el mismo modo de entrar que el que Orlando hacía en As You Like It, sino que nos sentimos integrados en un ámbito de aproximación a la tragedia que Shakespeare maneja para cubrir un proyecto de catharsis. Apenas hemos entrado en ese territorio escénico ya hay una mención a los sucesos que van a plantearse y hasta se nos coloca ante unos hechos que desencadenan la posterior intervención del "antagonista". Llegados a este punto podríamos señalar que el dilema entre "lo que se querría conseguir" y "lo conseguido" surge como una confrontación entre los primeros habitantes de ese escenario que hasta hace unos momentos estaba vacio. El "entra" se puede entender como una integración al orden que se está proponiendo y los "entran-

19 The Merchant of Venice. The New Shakespeare Edited by Sir Arthur Quiller Couch and John Dover Wilson, Cambridge. At the University Press, 1969, p. 122.

20 The Merchant of Venice. The New Shakespeare, op. cit. pp 122/123. 


\section{CANDIDO PEREZ GALLEGO}

tes" lo hacen con una misión muy específica de proponer un equilibrio con lo que se produzca después.

Romeo and Juliet nos lleva a consideraciones originales. Tras la separación del "coro" que nos advierte de la enemistad de las dos casas de Verona, vamos a "a public place" donde "enter Sampson and Gregory, of the house of Capulet, with swords and bucklers on" que ya nos advierte de un principio inicial de tensión y enemistad con alguien que va a sugir. Este arranque no es el mismo que el de obras donde el papel del "coro" queda asumido en un "prólogo", como Troilus and Cressida o Gower en Pericles. Ahora es cuando debemos entrar en el modo de resolver los romances. Las cuatro últimas obras de Shakespeare presentan curiosas peculiaridades como ya Tillyard ha señalado ${ }^{20}$. Asistimos a un ritual de recuperar lo perdido así como un emblema del renacer. Cymbeline se abre en el jardín del palacio del Rey de Bretaña donde dos caballeros hablan para indicarnos lo que está ocurriendo y comentan lo ocurrido con su hija Imogen "She's weded/Her husband banished; she imprisoned. All/ Is outward sorrow, though I think the king/ Be touched at very heart" $(I, 1)$. Este modo de definir la situación es muy convencional pero nos advierte que la vox populi ha irrumpido en el escenario para dar el valor de un rumor. The Winters's Tale tiene un original punto de partida, muy bello y prometedor. "Sicilia. A long gallery in the palace of Leontes, with doors at either end; chairs, tables, etc. Enter Camillo and Archidamus". Esta disposición nos remite a las formaciones bipolares que antes hemos visto. Acaba de entrar en el escenario dos caballeros, dos nobles el uno de Sicilia y el otro de Bohemia y el tema de la conversación es el de una invitación que se acaba de formular. Está en el aire ese dilema Sicilia-Bohemia que será el eje central de toda la obra pero tenemos la sospecha de que esa separación y hasta despedida nos remite, metafóricamente, a otra de mayores consecuencias y que sea una simbología de la enemistad Leontes-Polixenes.

The Winter's Tale hace de la cordialidad un preámbulo al problema que va a plantearse. Pronto entrarán Leontes, Hermione, Mamillius y Polixenes y el conflicto estará asomando. Pericles nos coloca - pronto- ante Gower tal vez esta alusión al autor de Confessio Amantis sea una apertura a un orden nuevo que se va a establecer en esa metáfora de búsqueda que pronto surgirá, pero será The Tempest donde descubramos un principio sutil y profundo: "A tempestuous noise of thunder and lightning hears. The waits of a ship is seen, seas breaking over it". Tal coreografía desprende el problema que la obra nos va a brindar, y este detalle de referirnos al "ship-master" y al "boatswain" es ejemplo claro de que por fin los niveles sociales inferiores han hecho su aparición. Ellos dominan a Alonso Rey de Nápoles y su comitiva y son los verdaderos dueños de una situación que se desprende desde la más brutal humildad. Cuando Gonzalo diga "Good, yet remember whom thou hast aboard" $(I, 1)$ nos encontraremos con que el trabajo ha desplazado al poder y se ha conseguido un auténtico dilema entre una conspiración que se presente en sus más evidentes formas. 
Las imágenes de Imogen, Marina, Perdita y Miranda son como el nexo que una la realidad a la fantasía, las portadoras de un emblema de reconciliación con el arte.

La auténtica realidad de esta escena cero que surge de la nada, es la necesidad que tenemos de colocarla inmediatamente en un espacio y tiempo. Las primeras conversaciones deben de ser lo bastante informativas como para saber que es lo que está ocurriendo ante nosotros y en el diálogo se van deslizando unos elementos que se refieren lo ausente, a lo ocurrido fuera de la escena: esta es la primera evidencia de una dinámica que funciona. Por un lado la realidad factual de estas frases que oimos y ese gesto contenido, pero también las alusiones que se empiezan a hacer ya, a partir de este momento, a alguien que debe irrumpir o a un problema que tendrá que surgir de modo más o menos disfrazado. Este es el sentido del "ghost" en Hamlet, al advertir que hay una prehistoria que es necesario reconstruir y para la que son válidos hasta los misterios sobrenaturales. Visto así el problema y observando la proximidad a una "teoría del conflicto" tendremos que advertir que el teatro es un proceso dialéctico para resolver, con la lógica del lenguaje y de los actos, un dilema entre realidad y fantasía. El problema del amor de Bassanio por Portia hay que resolverlo y para ello se necesita dinero: las próximas escenas habrán de ser una metáfora del "love" y "money" y hacia ellas deberá ir Shakespeare para encontrar una posible solución a esa necesidad que Bassanio ha confesado tener.

Este es el final de nuestro análisis que sólo tenía por meta descubrir la "teoría del principio". Pretendíamos advertir la mecánica coherente que desde las categorías aristotélicas de armonía transcurren en esa proyección dramática de unos sucesos que se van desarrollando de acuerdo a unas normas implacables. The Tempest nos viene como recuerdo imborrable y la dianoia escondida en la obra surge en la figura de Prospero, que como muy bien observa Esteban Pujals; "Este respeto al sabio Prospero para conservar la pureza, la libertad y la ilusión de la pareja enamorada, sólo puede compararse a su generosa actitud frente a los agentes del mal" 21 idea que nos remite a $\mathbf{J}$. Dover Wilson al ver una Morality bien/mal en Shakespeare, basada tal vez en el medievalismo de su primera producción. Pero no hay feudalismo moral y Ian Kott lo observa en su brillante estudio, solo hay una búsqueda del "mundo real"22 que incluso entre las aguas se puede deslizar insinuante. Esta es la garantía de que el orden de la fantasía

21 Drama, pensamiento y poesía en la literatura inglesa, por Esteban Pujals, Madrid: Rialp, 1965, p. 136.

22 "La verdadera Tempestad es sobrecogedora y severa, lírica y grotesca: es como todas las grandes obras de Shakespeare un apasionado reajuste de cuentas con el mundo real" Apuntes sobre Shakespeare por Jan Kott, Barcelona; Seix Barral, 1969 (1961) p. 355 . 


\section{CANDIDO PEREZ GALLEGO}

subsiste en Shakespeare, que está marcado por un brutal enfrentamiento con lo real, que nos lleva de nuevo a Hamlet -obra imposible de abandonar-y que nos hace reconsiderar la opinión lucida de Stanley Wells: "Hamlet's progress

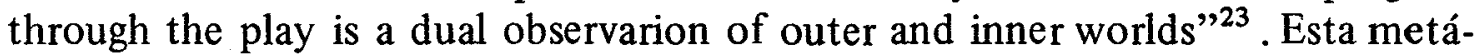
fora de la fusión de ámbitos nos lleva, para concluir, a los Four Quartets de T. S. Eliot. Hemos hecho un experimento en lo que signifique principio y final, y tratando de ver cómo ambos se juntan. Pensemos lo mismo "If all time is eternally present/ All time is unredeemable" como ese arranque de otro cuarteto que nos deja el problema planteado: "In my beginning is my end".

23 Shakespeare. The Writer and his Work por Stanley Wells, London; Longmans, 1978. p. 58 . 